\title{
TATA KELOLA PERUSAHAAN DAN RASIO KEUANGAN TERHADAP NILAI PERUSAHAAN MANUFAKTUR
}

\author{
YOHANNA ROSA ANGELINE \\ RUDI SETIADI TJAHJONO \\ Sekolah Tinggi IImu Ekonomi Trisakti, Jl. Kyai Tapa No. 20, Grogol, Jakarta, Indonesia \\ rudistjahjono@gmail.com, yohanna.rosaangeline@gmail.com
}

\begin{abstract}
The aim of this study is to obtain empirical evidence about the effect of corporate governance (audit committee, size of the commissioner's board, proportion of independent commissioner's board), firm size, and financial ratio (leverage, liquidity, activity, profitability) to firm value. Sample used in this study are all manufacturing companies listed in Indonesia Stock Exchange consistently during the period from 2015 until 2017. Sample selection method used was purposive sampling, there were 69 companies met the criteria, resulting 207 data are taken as sample. Research data were analyzed by doing hypothesis test using multiple regression method to determine the model of research. The results of this study show that proportion of independent commissioner's board, leverage, and profitability affect firm value. Audit committee, size of the commissioner's board, firm size, liquidity, and activity have no effect to value of the firm.
\end{abstract}

Keywords: Firm value, corporate governance, firm size, financial ratio

Abstrak: Tujuan penelitian adalah untuk mendapatkan bukti empiris apakah terdapat pengaruh corporate governance (komite audit, ukuran dewan komisaris, proporsi dewan komisaris independen), ukuran perusahaan, dan rasio keuangan (leverage, likuiditas, aktivitas, profitabilitas) terhadap nilai perusahaan. Sampel yang diambil dalam penelitian ini adalah seluruh perusahaan manufaktur yang terdaftar di Bursa Efek Indonesia secara konsisten selama periode 2015 sampai dengan 2017. Metode pemilihan sampel menggunakan purposive sampling, terdapat 69 perusahaan memenuhi kriteria sehingga diperoleh sebanyak 207 data sebagai sampel. Data penelitian ini dianalisis dengan melakukan uji hipotesis menggunakan metode regresi berganda dalam menentukan model penelitian. Hasil dari penelitian ini menunjukkan bahwa terdapat pengaruh proporsi dewan komisaris independen, leverage, dan profitabilitas terhadap nilai perusahaan. Sementara komite audit, ukuran dewan komisaris, ukuran perusahaan, likuiditas, dan aktivitas tidak berpengaruh terhadap nilai perusahaan.

Kata kunci: Nilai perusahaan, corporate governance, ukuran perusahaan, rasio keuangan

\section{PENDAHULUAN}

Seiring dengan perkembangan zaman, munculnya banyak bidang usaha baru membuat persaingan diantara perusahaan semakin ketat. Oleh karena itu, setiap perusahaan harus memiliki visi, misi, dan tujuan yang jelas untuk mempertahankan eksistensinya di dalam dunia bisnis. Pada umumnya perusahaan memiliki dua tujuan, yaitu tujuan jangka pendek dan tujuan jangka panjang. Tujuan jangka pendek suatu perusahaan adalah memperoleh laba yang maksimal dengan penggunaan sumber daya yang terbatas, sedangkan tujuan jangka 
panjang dari perusahaan adalah memaksimalkan nilai perusahaan itu sendiri. Semakin tinggi harga pasar saham, maka nilai perusahaan tersebut akan semakin meningkat. Nilai perusahaan yang tinggi akan menunjukkan tingginya kemakmuran para pemegang saham sehingga investor akan tertarik untuk melakukan investasi (Irayanti dan Tumbel 2014, 1474).

Cara perusahaan untuk mendapatkan modal dari para investor adalah dengan melakukan go public. Go public adalah suatu kegiatan dimana perusahaan melakukan penawaran surat berharga kepada masyarakat umum untuk pertama kalinya di Bursa Efek Indonesia (Harahap 2011, 131). Perusahaan go public biasanya menyertakan informasi yang relevan, seperti laporan keuangan yang memuat kondisi perusahaan secara keseluruhan. Informasi akuntansi tersebut berguna bagi investor untuk menilai keadaan keuangan perusahaan guna mengambil keputusan apakah investor akan menginvestasikan dananya pada saham perusahaan tersebut (Timbuleng et al. 2015, 547).

Tujuan dari penelitian ini adalah untuk mendapatkan bukti empiris bahwa terdapat pengaruh corporate governance (komite audit, ukuran dewan komisaris, proporsi dewan komisaris independen), ukuran perusahaan, dan rasio keuangan (leverage, likuiditas, aktivitas, profitabilitas) terhadap nilai perusahaan.

\section{Komite Audit}

Komite audit didefinisikan sebagai sekelompok orang yang bekerja secara profesional dan independen (Effendi 2016, 48). Komite audit memiliki peranan penting dalam pengendalian internal perusahaan untuk menjaga kredibilitas laporan keuangan dan memberikan opini mengenai wajar atau tidaknya laporan keuangan perusahaan (Siahaan 2013, 138). Menurut Komite Nasional Kebijakan Governance $(2006,15)$, apabila komite audit menjalankan fungsi dan tugasnya dengan baik, maka perusahaan akan memiliki keterbukaan termasuk dalam laporan keuangannya. Hal ini akan mempengaruhi minat investor terhadap perusahaan, sehingga akan meningkan nilai perusahaan.

$\mathrm{H}_{1}$ : Terdapat pengaruh komite audit terhadap nilai perusahaan.

\section{Ukuran Dewan Komisaris}

Dewan komisaris merupakan anggota perusahaan yang bertugas untuk mengawasi kebijakan dan kegiatan yang dilakukan oleh dewan direksi dan pihak manajemen perusahaan, sehingga kegiatan perusahaan dapat berjalan dengan lancar untuk mencapai tujuan utama perusahaan yaitu meningkatkan nilai perusahaan (Sakti dan Nugroho 2012). Namun, dewan komisaris juga memiliki batasan kewenangan, dimana dewan komisaris tidak diperbolehkan untuk terlibat dalam pengambilan keputusan operasional perusahaan.

$\mathrm{H}_{2}$ : Terdapat pengaruh ukuran dewan komisaris terhadap nilai perusahaan.

\section{Proporsi Dewan Komisaris Independen}

Komisaris independen atau yang dikenal dengan komisaris luar merupakan dewan komisaris yang berasal dari luar perusahaan dan tidak memiliki hubungan afiliasi dengan perusahaan dalam kondisi apapun. Dewan komisaris independen memiliki tanggung jawab untuk melindungi kepentingan para pemegang saham (Siahaan 2013, 139). Semakin tinggi jumlah dewan komisaris independen dalam perusahaan, diharapkan tugas pegawasan dan pemberian nasihat kepada direksi juga semakin efektif sehingga meningkatkan nilai perusahaan.

$\mathrm{H}_{3}$ : Terdapat pengaruh proporsi dewan komisaris independen terhadap nilai perusahaan.

\section{Ukuran Perusahaan}

Ukuran perusahaan dapat ditentukan berdasarkan total aset yang dimiliki oleh perusahaan (Rudangga dan Sudiarta 2016, 4398). Apabila total aset dari suatu perusahaan 
bernilai besar, maka dapat dikatakan perusahaan tersebut telah mencapai tahap kedewasaan. Pada umumnya, perusahaan yang berada dalam tahap kedewasaan memiliki arus kas yang bernilai positif, prospek jangka panjang yang baik, relatif lebih stabil, mampu menghasilkan laba bagi perusahaan, dan memiliki pengendalian yang baik dalam kondisi pasar, sehingga dapat menghadapi persaingan ekonomi yang terjadi (Siahaan 2013, 139). Besar kecilnya ukuran perusahaan akan berdampak pada kepercayaan investor terhadap perusahaan tersebut, sehingga akan mempengaruhi nilai perusahaan (Rudangga dan Sudiarta 2016, 4398).

$\mathrm{H}_{4}$ : Terdapat pengaruh ukuran perusahaan terhadap nilai perusahaan.

\section{Leverage}

Leverage atau solvabilitas merupakan rasio keuangan yang berfungsi untuk mengukur kemampuan perusahaan dalam membayar kewajibannya ketika perusahaan tersebut dibubarkan. Besar kecilnya rasio leverage tergantung dari jumlah pinjaman yang dimiliki perusahaan (Stiyarini dan Santoso 2016, 4). Proporsi utang yang tinggi dapat meningkatkan nilai perusahaan karena beban pajak yang perlu ditanggung oleh perusahaan relatif kecil. Oleh karena itu, leverage merupakan salah satu pertimbangan penting yang dapat mempengaruhi nilai perusahaan.

$\mathrm{H}_{5}$ : Terdapat pengaruh leverage terhadap nilai perusahaan.

\section{Likuiditas}

Likuiditas merupakan rasio keuangan yang berfungsi untuk mengukur kemampuan perusahaan dalam memenuhi kewajiban yang telah jatuh tempo. Kewajiban tersebut meliputi kewajiban kepada pihak dalam maupun pihak luar perusahaan. Apabila perusahaan memiliki nilai likuiditas yang tinggi, maka perusahaan cenderung memiliki dana internal yang besar untuk membiayai investasinya (Putra dan Lestari 2016, 4050). Secara teori, tingkat likuiditas memiliki pengaruh yang positif dengan nilai perusahaan (Sudiani dan Darmayanti 2016, 4551).

$\mathrm{H}_{6}$ : Terdapat pengaruh likuiditas terhadap nilai perusahaan.

\section{Aktivitas}

Aktivitas merupakan rasio keuangan yang berfungsi untuk mengukur tingkat efektivitas dan efisiensi perusahaan dalam memanfaatkan sumber daya yang ada. Sumber daya yang dimaksud meliputi seluruh aset yang dimiliki oleh perusahaan dalam menjalankan bisnisnya (Stiyarini dan Santoso 2016, 5). Menurut Erawati $(2015,76)$, tingkat aktivitas berbanding lurus dengan nilai perusahaan. semakin tinggi tingkat aktivitas, maka akan meningkatkan nilai perusahaan yang ditunjukkan dengan besarnya aliran kas yang diterima oleh perusahaan karena seluruh aset dapat dikelola secara efektif.

$\mathrm{H}_{7}$ : Terdapat pengaruh aktivitas terhadap nilai perusahaan.

\section{Profitabilitas}

Profitabilitas merupakan rasio keuangan yang berfungsi untuk mengukur kemampuan perusahaan dalam menghasilkan keuntungan atau laba selama satu periode tertentu (Rudangga dan Sudiarta 2016, 4406). Hasil pengukuran profitabilitas dapat digunakan untuk mengevaluasi kinerja perusahaan, apakah perusahaan telah bekerja secara efektif atau tidak (Stiyarini dan Santoso 2016, 6). 
Secara teori, tingkat profitabilitas berpengaruh positif terhadap nilai perusahaan (Erawati 2015, 77).

$\mathrm{H}_{8}$ : Terdapat pengaruh profitabilitas terhadap nilai perusahaan.

\section{METODE PENELITIAN}

Tabel 1 Prosedur Pemilihan Sampel

\begin{tabular}{clcc}
\hline No. & \multicolumn{1}{c}{ Keterangan } & Perusahaan & Data \\
\hline 1. & $\begin{array}{l}\text { Perusahaan manufaktur yang terdaftar di Bursa Efek } \\
\text { Indonesia secara konsisten selama periode 2015 sampai } \\
\text { dengan 2017. }\end{array}$ & 138 & 414 \\
2. $\begin{array}{l}\text { Perusahaan manufaktur yang tidak menerbitkan laporan } \\
\text { keuangan tahunan yang berakhir pada tanggal } 31\end{array}$ & $(3)$ & $(9)$ \\
$\begin{array}{l}\text { Desember selama periode 2015 sampai dengan 2017. } \\
\text { 3. } \begin{array}{l}\text { Perusahaan manufaktur yang tidak menyajikan laporan } \\
\text { keuangan dengan menggunakan mata uang rupiah (Rp). }\end{array}\end{array}$ & $(26)$ & $(78)$ \\
4. $\begin{array}{l}\text { Perusahaan manufaktur yang tidak melaporkan laba bersih } \\
\text { positif selama periode 2015 sampai dengan 2017. }\end{array}$ & $(40)$ & $(120)$ \\
\hline & $\begin{array}{l}\text { Total perusahaan manufaktur yang digunakan sebagai } \\
\text { sampel penelitian }\end{array}$ & 69 & 207 \\
\hline
\end{tabular}

Menurut Wijaya dan Sedana (2015, 4478) nilai perusahaan dapat diartikan sebagai jumlah yang bersedia dibayar oleh investor ketika perusahaan tersebut dijual, biasanya sering dikaitkan dengan harga saham. Semakin tinggi harga saham suatu perusahaan, maka kemakmuran para pemegang saham juga tinggi. Penelitian ini menggunakan Price to Book Value (PBV) untuk mengukur nilai perusahaan (Siahaan 2013, 138).

Komite audit merupakan sekelompok orang yang bekerja secara profesional dan independen (Effendi 2016, 48). Komite audit bertanggung jawab untuk menjaga kredibilitas laporan keuangan dan memberikan opini mengenai wajar atau tidaknya laporan keuangan perusahaan (Siahaan 2013, 138). Komite audit diukur dengan jumlah komite audit (Perdana dan Raharja 2014, 4)

Dewan komisaris merupakan anggota perusahaan yang bertanggung jawab untuk mengawasi kebijakan dan kegiatan yang dilakukan oleh dewan direksi dan pihak manajemen, sehingga kegiatan perusahaan dapat berjalan dengan lancar (Sakti dan Nugroho 2012). Ukuran dewan komisaris diukur menggunakan jumlah anggota dewan komisaris (Firdausya et al. 2013, 413).

Komisaris independen merupakan dewan komisaris yang berasal dari luar perusahaan dan tidak memiliki hubungan afiliasi dengan perusahaan dalam kondisi apapun. Tanggung jawab dewan komisaris independen adalah melindungi kepentingan para pemegang saham (Siahaan 2013, 139). Proporsi dewan komisaris independen diukur menggunakan perbandingan antara anggota dewan komisaris independen terhadap jumlah anggota komisaris independen (Perdana dan Raharja 2014, 5).

Ukuran perusahaan merupakan salah satu indikator untuk menilai apakah perusahaan tersebut berskala besar atau kecil, dimana ukuran perusahaan dapat ditentukan berdasarkan total aset yang dimiliki oleh suatu 
perusahaan (Rudangga dan Sudiarta 2016, 4398). Ukuran perusahaan diukur menggunakan rumus log total aset (Siahaan 2013, 139).

Leverage merupakan rasio keuangan yang berfungsi untuk menunjukkan seberapa besar proporsi utang yang dimiliki perusahaan digunakan untuk membiayai kegiatan operasionalnya. Pada penelitian ini, leverage diukur menggunakan proksi Debt to Asset Ratio (Siahaan 2013, 139).

Likuiditas merupakan rasio keuangan yang berfungsi untuk mengukur kemampuan perusahaan dalam memenuhi kewajiban yang telah jatuh tempo (Putra dan Lestari 2016, 4050). Pada penelitian ini, likuiditas diukur menggunakan proksi Current Ratio (Gitman dan Zutter 2015, 119).

Aktivitas merupakan rasio keuangan yang berfungsi untuk mengukur efektivitas dan efisiensi dari aset perusahaan dalam menghasilkan penjualan tertentu. Aset yang dimaksud adalah persediaan sebagai elemen utama dari modal kerja aset yang selalu mengalami perputaran. Pada penelitian ini, aktivitas diukur menggunakan proksi Inventory Turnover (Winarto 2015, 328).

Profitabilitas merupakan rasio keuangan yang berfungsi untuk mengukur kemampuan perusahaan dalam menghasilkan keuntungan atau laba selama satu periode tertentu (Rudangga dan Sudiarta 2016, 4406). Pada penelitian ini, profitabilitas diukur menggunakan proksi Return on Asset (Stiyarini dan Santoso 2016, 7).

\section{HASIL PENELITIAN}

Berikut hasil uji t:

Tabel 2 Hasil Uji t

\begin{tabular}{lrc}
\hline \multicolumn{1}{c}{ Variabel } & B & Sig. \\
\hline (Constant) & $-18,748$ & 0,052 \\
KA & $-0,512$ & 0,642 \\
UDK & 0,062 & 0,824 \\
DKI & 20,987 & 0,000 \\
UP & 0,307 & 0,701 \\
DAR & 11,129 & 0,001 \\
CR & $-0,032$ & 0,906 \\
ITO & 0,217 & 0,080 \\
ROA & 69,373 & 0,000 \\
\hline
\end{tabular}

Sumber: Hasil Pengolahan Data

Tabel 2 menunjukkan bahwa komite audit memiliki nilai Sig. sebesar 0,642 dimana nilai tersebut lebih besar dari 0,05 sehingga dapat dikatakan bahwa tidak terdapat pengaruh komite audit terhadap nilai perusahaan, maka $\mathrm{H}_{1}$ tidak diterima. Hasil penelitian ini konsisten dengan penelitian yang dilakukan oleh Siahaan (2013, 141), Debby et al. $(2014,85)$, dan Mukhtaruddin et al. $(2014,8)$. 
Tabel 2 menunjukkan bahwa ukuran dewan komisaris memiliki nilai Sig. sebesar 0,824 dimana nilai tersebut lebih besar dari 0,05 sehingga dapat dikatakan bahwa tidak terdapat pengaruh ukuran dewan komisaris terhadap nilai perusahaan, maka $\mathrm{H}_{2}$ tidak diterima. Hasil penelitian ini konsisten dengan penelitian yang dilakukan oleh Wardoyo dan Veronica (2013, 143) serta Mukhtaruddin et al. $(2014,6)$.

Tabel 2 menunjukkan bahwa proporsi dewan komisaris independen memiliki nilai Sig. sebesar 0,000 dimana nilai tersebut lebih kecil dari 0,05 sehingga dapat dikatakan bahwa terdapat pengaruh proporsi dewan komisaris independen terhadap nilai perusahaan, maka $\mathrm{H}_{3}$ diterima. Proporsi dewan komisaris independen memiliki nilai beta sebesar 20,987 artinya proporsi dewan komisaris independen berpengaruh positif terhadap nilai perusahaan. Hasil penelitian ini konsisten dengan penelitian yang dilakukan oleh Muryati dan Suardikha $(2014,423)$ serta Onasis dan Robin $(2016,12)$.

Tabel 2 menunjukkan bahwa ukuran perusahaan memiliki nilai Sig. sebesar 0,701 dimana nilai tersebut lebih besar dari 0,05 sehingga dapat dikatakan bahwa tidak terdapat pengaruh ukuran perusahaan terhadap nilai perusahaan, maka $\mathrm{H}_{4}$ tidak diterima. Hasil penelitian ini konsisten dengan penelitian yang dilakukan Winarto $(2015,346)$, Farooq (2016, 76), dan Rupilu (2011, 118).

Tabel 2 menunjukkan bahwa leverage memiliki nilai Sig. sebesar 0,001 dimana nilai tersebut lebih kecil dari 0,05 sehingga dapat dikatakan bahwa terdapat pengaruh leverage terhadap nilai perusahaan, maka $\mathrm{H}_{5}$ diterima. Leverage memiliki nilai beta sebesar 11,129 artinya leverage berpengaruh positif terhadap nilai perusahaan. Hasil penelitian ini konsisten dengan penelitian yang dilakukan oleh Onasis dan Robin (2016, 14), Gill dan Obradovich (2012, 8), serta Rudangga dan Sudiarta (2016, 4415).

Tabel 2 menunjukkan bahwa likuiditas memiliki nilai Sig. sebesar 0,906 dimana nilai tersebut lebih besar dari 0,05 sehingga dapat dikatakan bahwa tidak terdapat pengaruh likuiditas terhadap nilai perusahaan, maka $\mathrm{H}_{6}$ tidak diterima. Hasil penelitian ini konsisten dengan penelitian yang dilakukan oleh Stiyarini dan Santoso $(2016,17)$, Timbuleng et al. $(2015$, 555), serta Erawati $(2015,83)$.

Tabel 2 menunjukkan bahwa aktivitas memiliki nilai Sig. sebesar 0,080 dimana nilai tersebut lebih besar dari 0,05 sehingga dapat dikatakan bahwa tidak terdapat pengaruh aktivitas terhadap nilai perusahaan, maka $\mathrm{H}_{7}$ tidak diterima. Hasil penelitian ini konsisten dengan penelitian yang dilakukan oleh Winarto $(2015,346)$, Stiyarini dan Santoso $(2016,17)$, serta Sianturi $(2015,293)$.

Tabel 2 menunjukkan bahwa profitabilitas memiliki nilai Sig. sebesar 0,000 dimana nilai tersebut lebih kecil dari 0,05 sehingga dapat dikatakan bahwa terdapat pengaruh profitabilitas terhadap nilai perusahaan, maka $\mathrm{H}_{8}$ diterima. Profitabilitas memiliki nilai beta sebesar 69,373 artinya profitabilitas berpengaruh positif terhadap nilai perusahaan. Hasil penelitian ini konsisten dengan penelitian yang dilakukan oleh Winarto $(2015,346)$, Stiyarini dan Santoso $(2016,17)$, serta Rinnaya et al. (2016).

\section{PENUTUP}

Hasil dari penelitian ini menunjukkan bahwa terdapat pengaruh proporsi dewan komisaris independen, leverage, dan profitabilitas terhadap nilai perusahaan. Komite audit, ukuran dewan komisaris, ukuran perusahaan, likuiditas, dan aktivitas tidak berpengaruh terhadap nilai perusahaan. Penelitian ini memiliki beberapa keterbatasan yang perlu diperhatikan, seperti: data dalam penelitian tidak berdistribusi normal, hasil penelitian ini masih mengalami masalah uji asumsi klasik yaitu heteroskedastisitas, dan delapan variasi variabel independen yang digunakan dalam penelitian ini hanya mampu 
menjelaskan variasi variabel dependen sebesar $60,1 \%$.

Adapun rekomendasi yang dapat disarankan adalah sebagai berikut: diharapkan penelitian selanjutnya dapat menambah data untuk mengatasi data yang tidak berdistribusi normal. Selain itu, penelitian selanjutnya diharapkan dapat melakukan transformasi data variabel, baik variabel bebas, variabel terikat, ataupun keduanya, sehingga asumsi homoskedastisitas dapat terpenuhi. Penelitian selanjutnya juga diharapkan dapat menambah variabel independen lain yang diduga memiliki pengaruh terhadap nilai perusahaan, seperti: Corporate Social Responsibility (CSR) disclosure, kepemilikan institusional, dan kebijakan dividend.

\section{REFERENCES:}

Debby, Julia Farah, Mukhtaruddin, Emylia Yuniarti, Dewa Saputra, dan Abukosim. 2014. Good Corporate Governance, Company's Characteristics and Firm's Value: Empirical Study of Listed Banking on Indonesian Stock Exchange. GSTF Journal on Business Review (GBR), Vol. 3, No. 4: 81-88.

Effendi, Muh. Arief. 2016. The Power of Good Corporate Governance: Teori dan Implementasi. Jakarta: Salemba Empat.

Erawati, Diana. 2015. Pengaruh Likuiditas, Manajemen Aset, Manajemen Liabilitas, dan Profitabilitas terhadap Harga Saham Pasar/Buku pada Perusahaan Makanan dan Minuman yang Terdaftar di BEI Periode Tahun 2008-2012. E-Jurnal IImu Manajemen MAGISTRA, Vol. 1, No. 1: 71-87.

Farooq, Muhammad Azhar dan Ahsan Masood. 2016. Impact of Financial Leverage on Value of Firms: Evidence from Cement Sector of Pakistan. Research Journal of Finance and Accounting, Vol. 7, No. 9: 73-77.

Firdausya, Zanera Saroh, Fifi Swandari, dan Widyar Effendi. 2013. Pengaruh Mekanisme Good Corporate Governance (GCG) pada Nilai Perusahaan (Studi pada Perusahaan yang Masuk Indeks LQ45 di Bursa Efek Indonesia). Jurnal Wawasan Manajemen, Vol. 1, No. 3: 407-423.

Gill, Amarjit dan John D. Obradovich. 2012. The Impact of Corporate Governance and Financial Leverage on the Value of American Firms. International Research Journal of Finance and Economics, Vol. 9, No. 1: 1-14.

Gitman, Lawrence J. dan Chad J. Zutter. 2015. Principles of Managerial Finance 14th Edition. England: Pearson.

Harahap, Agus Salim. 2011. Proses Initial Public Offering (IPO) di Pasar Modal Indonesia. Forum IImiah, Vol. 8 , No. 2: 131-138.

Irayanti, Desi dan Altje L. Tumbel. 2014. Analisis Kinerja Keuangan Pengaruhnya terhadap Nilai Perusahaan pada Industri Makanan dan Minuman di BEl. Jurnal EMBA, Vol. 2, No. 3: 1473-1482.

Komite Nasional Kebijakan Governance. 2006. Pedoman Umum Good Corporate Governance Indonesia. Jakarta: Komite Nasional Kebijakan Governance.

Mukhtaruddin, Relasari, dan Messa Felmania. 2014. Good Corporate Governance Mechanism, Corporate Social Responsibility Disclosure on Firm Value: Empirical Study on Listed Company in Indonesia Stock Exchange. International Journal of Finance and Accounting Studies, Vol. 2, No. 1: 1-10.

Muryati, Ni Nyoman Tri Sariri dan I Made Sadha Suardikha. 2014. Pengaruh Corporate Governance pada Nilai Perusahaan. E-Jurnal Akuntansi Universitas Udayana, Vol. 9, No. 2: 411-429.

Onasis, Kristie dan Robin. 2016. Pengaruh Tata Kelola Perusahaan terhadap Nilai Perusahaan pada Perusahaan Sektor Keuangan yang Terdaftar di BEI. Bina Ekonomi, Vol. 20, No.1: 1-22. 
Perdana, Ramadhan Sukma dan Raharja. 2014. Analisis Pengaruh Corporate Governance terhadap Nilai Perusahaan. Diponegoro Journal of Accounting, Vol. 3, No. 3: 1-13.

Putra, A.A. Ngurah Dharma Adi dan Putu Vivi Lestari. 2016. Pengaruh Kebijakan Dividen, Likuiditas, Profitabilitas dan Ukuran Perusahaan terhadap Nilai Perusahaan. E-Jurnal Manajemen Unud, Vol. 5, No. 7: 4044-4070.

Rinnaya, Ista Yansi, Rita Andini, dan Abrar Oemar. 2016. Pengaruh Profitabilitas, Rasio Aktivitas, Keputusan Pendanaan, Keputusan Investasi terhadap Nilai Perusahaan (Studi Empiris Pada Perusahaan Manufaktur yang Terdaftar di BEI Tahun 2010-2014). Journal Of Accounting, Vol. 2, No. 2.

Rudangga, I Gusti Ngurah Gede dan Gede Merta Sudiarta. 2016. Pengaruh Ukuran Perusahaan, Leverage, dan Profitabilitas terhadap Nilai Perusahaan. E-Jurnal Manajemen Unud, Vol. 5, No. 7: 4394-4422.

Rupilu, Wilsna. 2011. Pengaruh Mekanisme Corporate Governance terhadap Kualitas Laba dan Nilai Perusahaan pada Perusahaan Manufaktur yang Terdaftar di Bursa Efek Indonesia. Jurnal Akuntansi, Manajemen Bisnis dan Sektor Publik (JAMBSP), Vol. 8, No. 1: 101-127.

Sakti, Kaharudinsyah Leon dan Penta Nugroho. 2012. Pengaruh Good Corporate Governance terhadap Hubungan antara Kinerja Keuangan dengan Nilai Perusahaan. Jurnal Manajemen, Akuntansi dan Ekonomi Pembangunan, Vol. 10, №. 2.

Siahaan, Fadjar O.P. 2013. The Effect of Good Corporate Governance Mechanism, Leverage, and Firm Size on Firm Value. GSTF International Journal on Business Review (GBR), Vol. 2, No. 4: 137-142.

Sianturi, M. Wanti Ernita. 2015. Pengaruh Kinerja Keuangan terhadap Nilai Perusahaan Manufaktur Sektor Industri Barang Konsumsi di BEl. E-Journal IImu Administrasi Bisnis. Vol. 3, No. 2: 282-296.

Stiyarini dan Bambang Hadi Santoso. 2016. Pengaruh Kinerja Keuangan terhadap Nilai Perusahaan pada Perusahaan Jasa Telekomunikasi. Jurnal IImu dan Riset Manajemen, Vol. 5, No. 2: 1-21.

Sudiani, Ni Kadek Ayu dan Ni Putu Ayu Darmayanti. 2016. Pengaruh Profitabilitas, Likuiditas, Pertumbuhan, dan Investment Opportunity Set terhadap Nilai Perusahaan. E-Jurnal Manajemen Unud, Vol. 5, No. 7: 45454547.

Timbuleng, Ferlen, Sientje C. Nangoy, dan Ivonne S. Saerang. 2015. Pengaruh Faktor Likuiditas, Leverage, NPM, dan ROI terhadap Nilai Perusahaan (Studi pada Perusahaan Consumer Goods yang Terdaftar di Bursa Efek Indonesia Periode 2010-2013. Jurnal EMBA, Vol. 3, No. 2: 546-557.

Wardoyo dan Theodora Martina Veronica. 2013. Pengaruh Good Corporate Governance, Corporate Social Responsibility, dan Kinerja Keuangan terhadap Nilai perusahaan. Jurnal Dinamika Manajemen, Vol. 4, No. 2: 132-149.

Wijaya, Bayu Irfandi dan I.B. Panji Sedana. 2015. Pengaruh Profitabilitas terhadap Nilai Perusahaan (Kebijakan Dividen dan Kesempatan Investasi sebagai Variabel Mediasi. E-Jurnal Manajemen Unud, Vol. 4, No. 12: 4477-4500.

Winarto, Jacinta. 2015. The Determinants of Manufacturer Firm Value in Indonesia Stock Exchange. International Journal of Information, Business and Management, Vol. 7, No. 4: 323-349. 